\title{
EFL Pre-Service Teachers' Perceptions of the Effects of Teaching Practicum Experiences on their Professional Identity Development
}

\author{
Trang Thi Minh Ly ${ }^{1}$ and Hue Thi Thanh Tran ${ }^{2}$ \\ ${ }^{1}$ School of Foreign Languages, Can Tho University, Can Tho, Vietnam \\ ${ }^{2}$ School of Foreign Languages, An Giang University, \\ An Giang, Vietnam
}

\begin{abstract}
Research into Vietnamese English as a foreign language (EFL) pre-service teachers' perceptions of the effects of teaching practicum experiences on their professional identity development. This paper reports a descriptive research to explore the perceptions of Vietnamese EFL pre-service teachers on the development of professional identities before and after English teaching practicum at high schools in Mekong Delta. Interviews were employed to collect data from 10 pre-service teacher participating on teaching practicum at high schools. The findings reported in this paper provide deep insight into the English pre-service teachers' professional identities when having experiences in teaching practicum and will significantly contribute to research on teaching professional identity, professional competences, and professional development of pre-service teachers in Vietnam.
\end{abstract}

Keywords: professional identity, pre-service teacher, English teaching practicum, professional competences

\section{Introduction}

In pedagogical environment, teacher professional identity is influenced by many factors including teaching competences, perceptions of their roles in the teaching and learning process, teaching motivation, and teaching contexts (Pennington \& Richards, 2016). Teaching professional identity certainly takes an important role in language teaching if a teacher constantly developing the goal of future career orientation and the image of a standard teacher. From the time of graduation, students who are educated and trained to become teachers need to have the right orientation of their professional identity from the theoretical transformation learned into practice. Ulvik, Helleve, and Smith (2018) stated that there was the need for bridging the gap between theories students learnt from the university coursework and practical teaching environment. In Vietnam, English language has become a vital communication language used for economic development since the opening of the borders to the world in 1986. According to Decision 2080/QĐ-TTg (2017), English has become a compulsory foreign language subject which has taught from primary to tertiary institutions in Vietnam (Vietnamese Prime Minister, 2017). Given this, teaching and learning English has been deeply cared than ever. The training of educational human resources, especially English teachers, plays a huge role in the implementation of the national language project. However, the awareness of students in English pedagogy in professional development and professional identity is still a problem in teacher training. Accordingly, students understand their professional identity is still very vague. Therefore, it is necessary to identify what influences EFL preservice teachers' professional identity. The present study investigates Vietnamese EFL pre-service teachers' teaching practicum experiences and how these experiences affect their professional identity development. The current study attempted to answer the following questions:

1. How do teaching practicum experiences support Vietnamese EFL pre-service teachers' professional identity development?

2.How do teaching practicum experiences challenge Vietnamese EFL pre-service teachers' professional identity development? 


\section{Review of Literature}

\subsection{Identity and teacher professional identity} Identity is simply defined as what individuals believe about themselves, or a model that each person consults to understand himself/herself, especially during situations in which his/her choice play a decisive role (Salehnia \& Ashraf, 2015; Zlatković et al., 2012; Beijaard et al., 2000). They document that the self-concept is a fundamental internal standard which controls and directs an individual's behavior and activities. To some scholars, identity refers to relation to self-image (Chong \& Low, 2008), selfesteem (Zivkovic, 2016); Salehnia \& Ashraf, 2015), and job motivation (Canrinus et al., 2012; Canrinus, 2011). They determine that the levels of people' selfimage, self-esteem and job motivation have a significant influence on their performance and perception about themselves. Additionally, "the concept of identity thus reflects how individuals see themselves and how they enact their roles within different settings" (Richards, 2010, p.110). An individual's identity is developed through interactions with others in a specific social situation where social communication occurs. Actually, teachers' identities are demonstrated when they take on a variety of roles within the classroom like the controller, the prompter, the resource, the assessor, the organizer, the participant, and the coach (LarsenFreeman \& Anderson, 2011). Therefore, when teachers change their mind about themselves, their roles and their competences, their identity will be changed. Accordingly, teacher's professional identity is considered as the image of the teacher in each appropriate role. On the other hand, "one of the things that a person has to learn when he or she becomes a language teacher is what it means to be a teacher" (Richards, 2010, p.110). From this perspective, teachers' professional identity can be defined by how a teacher identifies him or herself in the field of teaching. Therefore, there is an interest in the teachers' professional identity in how teachers answer questions like "who am I as a teacher?" and "what kind of teacher do I want to become?" (Beijaard et al., 2004). According to Pillen and colleagues (2013), teachers' professional identity refers to the way teachers think about themselves as professionals and how they deal with the interactions with students and others.

\subsection{Teachers' professional competences in} identity construction

Teachers' professional identity is constructed with the classification of language teachers' professional competences (Pennington \& Richards, 2016). Pennington and Richards (2016) classify the sequence of competences into two categories including Foundational Competences of Language
Teacher Identity and then Advanced Competences of Language Teacher Identity.

The pre-service teachers' mentors have not only effected their teaching but also their desire to continue with teaching and grow professionally. Besides, pre-service teachers' perceptions of how their peers handle the assignment and assessment also provoke their behavior in professional identity development. In addition, teachers' relationship with students is central to determine teacher professional identity (Beijaard, 1995). Contemporaneously, the activities in teaching practicum that impact on preservice teachers' professional identity development also need to be discovered.

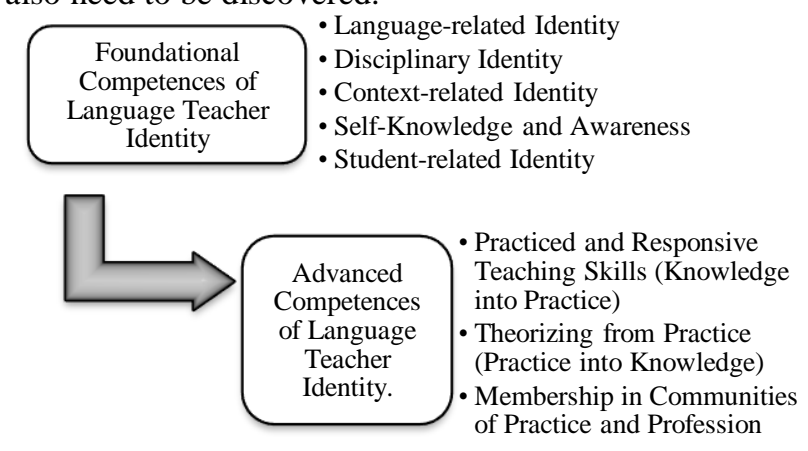

Fig. 1 The classification of language teachers' professional competences (Pennington \& Richards, 2016)

\subsection{High school teachers' national professional standards.}

Professional standard of teachers is a system of qualities and competencies that teachers need to achieve in order to implement the task of teaching and educating students at general education institutions (MOET, 2018). High school teachers' professional standards are set as a basis for high school teachers to assess their qualities and capabilities; formulating and implementing plans on training in quality and fostering professional and professional competencies to meet the requirements of education renovation. In addition, the standards will serve as a basis for state management agencies to study, build and implement regimes and policies to develop the capacity of general teachers. According to the human resource development program and teaching professional standards of MOET (2018), students trained to become future teachers require to meet special standards, including: (1) Teacher quality; (2) Professional development; (3) Building an educational environment; (4) Develop relationships between schools, families and society; and (5) Using foreign languages or ethnic languages, applying information technology, exploiting and using technological equipment in teaching and education

\subsection{Teaching practicum}

Teaching practicum is period of practical experience is also called by various terms like clinical 
experience, student teaching, or teaching practice (Carrington, Kervin, \& Ferry, 2008). It is also called internships or work placement programs (Marais \& $\mathrm{Nel}, 2018)$. In the framework of this research, the concept of teaching practicum is used as a one of the key definitions. Teaching practicum is an important stage in examining the student's theoretical and practical preparation for their work independently, and forms the vast capacity for creativity to address the work of one future teachers. In Vietnam, teaching practicum is compulsory in the program of training teachers at all universities. It is a course of study designed especially for the preparation of teachers that involves the supervised practical application of previously studied pedagogical knowledge and skills.

\subsubsection{Objectives of teaching practicum}

According to Ivanova and Skara-MincLne (2016), practicum programs are designed to provide students with practical work experience and emphasize the importance of learning by doing. They help students transfer their knowledge to actual work. Practicums can also open many opportunities to network and make important contacts within the industry (Ivanova and Skara-MincLine, 2016). Pre-service teachers are also provided with opportunities for a number of encounters with students in schools. This means that student teachers are not only know how to teach effectively in class but are also able to handle co-curricular activities as well. Besides, Turbill and Kervin (2007) determined in their study that practicum experiences activated the process of bridging the gap between theory and practice for the pre-service teachers and most importantly led to the beginnings of pre-service teachers developing a professional identity of what it means to 'be a teacher'. In short, teaching practicum program is to equip future teachers with the essential experiences that can lead to the development of their professional competencies.

In Vietnam, practicum at high school is an important part of the teacher training process, which is implemented in the fourth year of the teacher training program. According to the Teacher Training Guidelines of Ministry of Education and Training (MOET) on practicum for pre-service teacher training, teaching practicum provide pre-service teacher with opportunities to practice theories in teaching and learning practices and to develop individual teaching and learning theories. The main aim of teaching practicum is to help direct contact with their careers in the future.

\subsubsection{Participants of teaching practicum}

There are three main groups of personnel involved in practicum program in teacher education curriculum. They are (1) pre-service teachers - fourth year students in majors of teacher education - who completed the courses of observation practicum, principles and methodology in teaching, (2) school-

\section{ISSN 2455-6378}

based mentors who are teachers from high schools, and (3) university-based supervisors who are teachers and staff from related schools of university, department of education and training.

(1) Pre-service teachers, known as student teachers, is used to describe students who are enrolled in a teacher preparation program and working toward teacher certification.

(2) University-based supervisors is in charge of mastering teaching practicum plan; working with the school on the organization of the pre-service teachers' delegation, and receiving the information about the school.

(3) School-based mentors in practicum program take the role of exchanging of teaching experience, learning and training situation of the class and each student. They also instruct the internship activities of the students in accordance with the guidance and practice guidelines. In our study, we use the terms of mentors for this group of personnel.

\subsubsection{Characteristics of teaching practicum}

The periods of teaching practicum in the teacher training program of the university is in the eighth semester and conducted in continuous practice about 8 weeks (usually from January to April, the beginning of the second semester of the fourth year students) at high schools and primary schools. Preservice teachers are organized groups for each school, the members in each group include: a universitybased supervisor is a lecture in university, heads of, deputy heads and small professional group leaders are students.

In the process of teaching practicum, pre-service teacher not only has the opportunity to learn from the instructor, from other teachers in the school, but also from fellow students in the field. As a result, preservice teacher is divided into small groups with the same expertise to carry out the assignment, observe in the same group or teach in the same class. This helps pre-service teachers have the opportunity to cooperate, discuss, jointly develop the master plan, teaching and solving problems facing in the process of studying and practicing; share ideas and experiences; build up a relationship of mutual trust. This organization will help pre-service teachers feel more confident and learn more experience.

According to Guidelines on teaching practicum for pre-service teacher training, contents of teaching practicum of pre-service teachers focus on four work groups: (1) explore the reality of education at high schools; (2) practice teaching; (3) practice classroom management; (4) complete the records and write the report.

(1) Explore the reality of education at high schools: pre-service teachers familiarize themselves with the activities and organizational structure of high schools, students and their parents' situations, characteristic education in the local area, types of records and classroom situations. 
(2) Practice teaching: pre-service teachers build teaching plan according to each week and the full session; observe teaching activities and make lesson plan; design teaching aids; professional teach according to the approval of mentors (there are eight periods are assessed by the mentors).

(3) Practice homeroom work: through form teachers, groups of pre-service teachers (including 2 - 4 members) develop and implement the weekly and full session classroom management plans, observe the classroom management periods of mentor and ensure that there are 4 periods of practice classroom management assessed by the mentors. Besides, teachers are required to attend and instruct student in outside activities at high schools.

(4) Complete the records and write the report: after conducting all required activities in teaching practicum, pre-service teacher have to complete all reports, records and forms as prescribed in the pedagogic apprenticeship record.

2.5 The impact of practicum on pre-service teachers' professional identity

Several studies have addressed impact of practicum on pre-service teachers' professional identity were reported (e.g., Pillen et al., 2013; Tran \& Sanchez, 2016; Nguyen, 2017; Zhu \& Zhu, 2018; Ulvik et al., 2018).

The study by Pillen et al. (2013) presents an overview of the tensions regarding professional identity that a group of 24 beginning teachers experienced. After interviewing, they reported conflicts were seen to be the tensions they face when pedagogical practice. Therefore, students with the role of teachers had the enthusiasm to learn how to cope with and reconcile the tensions that were accompanied by helplessness, frustration or anger. The author stated that teachers with high passion and experience should pay serious attention to tensions related to professional identity of beginning teachers and support them in better ways in teaching practice.

The study by Tran and Sanchez (2016) has aimed to address the gap by adopting a holistic perspective to investigate the professional identity of two Vietnamese English teachers. Their narratives indicate that identity formation is a complex process in which professional and personal factors intermingle. The study examined the Vietnamese English teachers' identity formation via a case study design using interviews with two teachers about their background and auto-biographical semi-structured. The findings reinforce the conclusions drawn in some previous studies about teacher identity formation as a complex process involving professional and personal factors. Additionally, the results clarify the role of formal and informal pretraining learning experiences in the formation of language teacher identity both inside and outside the classroom.

\section{ISSN 2455-6378}

Another study by Nguyen (2017) reported on how Maria (pseudonym), a non-native English speaker and pre-service teacher of English as an additional language, developed her professional identity during the practicum in an Australian secondary school. The study data was collected through interviews with Maria before, during and after a practicum, her reflections, and an interview with her school mentor and relevant documents. The findings show that Maria experienced conflicts between her multiple identities of a non-native English speaker, student, becoming teacher, and classroom teacher; between her mentors' teaching approach and that of her own; and between her practice and rules. Both mentors and pre-service teachers can optimize their strengths through drawing connections between their backgrounds and the current teaching

Zhu and Zhu's study (2018) carried out the international study that was conducted about preservice teachers' professional identity transformation during practicums in China and the USA collaboratively. Data collected from this international research consist of semi-structured interviews and metaphor-themed written reflections. The findings expressed the participants' professional identity at the start and the end of the teaching practicums. In the teaching practicum, the participants shared four themes associated with their metaphorical professional identity formation. These four themes revolve around their self-perceptions of teachers' roles and responsibilities, the felt inadequacy of professional knowledge and capability in teaching, the transition shock from the university settings to the placement schools, and the dynamic relationship with the school-based mentors.

Within the context of Norway, Ulvik, Helleve and Smith (2018) investigated the role of work placement in the integration of practical skills and theoretical knowledge in teacher education. They let student teacher discuss with three main themes including (1) the placement context; (2) the difference between learning on campus and in the practice field; and finally (3) the outcome of field experiences. The sample in the sub-study was 21 self-selected students from three different teacher education programs at two universities in Norway. The results indicated that both practice and theory were necessary to cooperate and complement each other. To become a teacher, students were required to learn to practice, something that theory can contribute. Therefore, practicum was considers as further training for teacher education to promote students in a profession and a feeling of being a teacher.

\section{Materials and Methods}

The researcher follows the qualitative research method that provides descriptions about the practicum experiences and the pre-service teachers' 
professional identity. The research focuses primarily on exploring the teacher's perceptions of pre-service teachers' professional identity after practicum period so all the meanings identified in a particular context may have different perspectives from different people. Qualitative research offer rich and detailed information in understanding people's experiences. It is the collection and analysis of comprehensive narrative data to gain insights into a particular phenomenon of interest (Gay, Mills, \& Airasian, 2012) We selected participants resulting in a final sample of 10 pre-service teachers who volunteered to join the interviews. Among them, there are 6 female Pre-service teachers $(60 \%)$ and 4 male Pre-service teachers $(40 \%)$. In this study, face-to-face interviews was used to obtain in-depth information about a participant's thoughts, beliefs, knowledge, reasoning, motivations, and feelings about perceptions of teacher's role, teaching methodology and teaching environment. There were two interview stages with pre-service teachers that were administrated including interviews 1 or preinterviews was conducted before the teaching practicum to explore their self-perceptions as EFL teachers, and their expectations on the effects of the practicum on their professional competences and professional identity; interviews 2 or post-interview was conducted after the teaching practicum to explore their experiences, and their reflections on the effects of the practicum on their professional competences.

\section{Results and Discussion}

4.1 Pre-service teachers' expectations before the teaching practicum

4.1.1 EFL teachers' roles at high schools and the role of teaching practicum

Most teachers have their own positive opinion about the roles of EFL teachers at high schools as well as the role of teaching practicum period. Nine out of ten pre-services teachers stated that English teachers play vital roles in teaching and learning process. Particularly, four pre-service teachers stated that English as well as teaching English is very essential and important in the modern life. Three pre-service teachers thought that teaching English is very meaningful is that because it conveys knowledge to students, and creates joys for both teachers and high school students. Here is one of their speeches:

I think that my teaching profession is very important. The first is to bring knowledge, which is obvious because I enlighten people, give people literacy. Secondly, I think it is more important that teaching is not only about teaching knowledge but also educating people about personality. (PT3, Interview 1 extract)

4.1.2 Teaching motivation and confidence

Teachers expected that they would have higher teaching motivation after the teaching practicum. They predicted major factors influencing their

\section{ISSN 2455-6378}

teaching motivation in the future not only from mentors and students but also from their teaching context or even their own thought when they selected teaching as their profession.

I think that teaching practicum will help me get used to the teaching environment, and give me more confidence when standing in front of the class. When I practiced teaching at university, I was standing in front of my friends, not standing in front of my students. It is different, I think when I teach, I will be more confident. There is no fear, and it makes me try harder, motivates me to do lesson plans or study more thoroughly, to prepare strong knowledge (PT2, Interview 1 extract)

\subsubsection{Teaching competences}

Most of teachers expected to develop practical teaching competences at high school. They were aware of their own weaknesses in teaching competences and predicted to have difficulties in solving pedagogical situations. Nevertheless, they hoped that the shortcomings in teaching competences will be improved with the help of mentors and teaching communities during the teaching practicum period.

I think this practicum will make me more socially realistic than just learning theory. At university, I feel like I study the theory too much. When I practice teaching at high school, I will know how the students are, and I will learn more about teaching methods than just hearing or reading in method books or methods that teachers teach, then I will be more active in teaching. I think so. Besides, when I know much more students' qualifications, I will have a more appropriate method. (PT7, Interview 1 extract).

In terms of expertise, I hope the mentor will help me with more professional knowledge. For example, how about teaching skills because I still have problems communicating with students, I am not close to students, my method I use may not explain what that is, so I still have making it difficult for students to teach. (PT4, Interview 1 extract).

4.1.4 Expectations about mentors, peers and students All teachers expected to gain positive relationship and interaction with their mentors, peers and students. They hoped that their mentors would instruct them in teaching and inspire them to continue their teaching in the future.

Firstly, everyone wants their mentor to be easy. Secondly, I want the mentor to be enthusiastic and point out which I am wrong and how I can overcome this problem. (PT9, Interview 1 extract).

Whereas, their peers would be willing to share their duties during teaching practicum and help each other to encounter pedagogical problem.

I find many things easier and two people have many opinions so I will select the best choice. My way is to spend time talking to my peers. For example, before teaching, we can talk together; or after class, if no one can participate in any other activity, we can talk to each other about information that may (not) be relevant to the homeroom class (PT10, Interview 1 extract). 
Besides, they also hoped that they would have many memorable memories with their high school students. "No significant learning can occur without any relationship" - We have to think "Children don't learn from people they don not like". That is, first we have to give students the mentality that we care about them. (PT1, Interview 1 extract)

\subsection{Pre-service teachers' experiences of} teaching practicum

4.2.1 EFL teachers' roles at high schools and the role of teaching practicum

After teaching practicum period, most teachers think English teachers are not an easy job. They also agreed that English teacher has something different than the teachers of other subjects. Because English is a language subject that not every student is gifted to learn, the role of an English teacher is not only to teach well but to inspire students to love English. Therefore, the role of an English teacher in high school is extremely important, affecting the motivation of learning English as well as forming the personality for students.

English teachers, as well as other teachers, have a mission to orient the personality of students and teach them to develop English proficiency for students. (PT10, Interview 2 extract)

I think teaching is difficult. It looks simple but really not simple. The teacher has to spend a lot of time, effort and dedication to be able to teach well. And, I think it's complicated but for people who love teaching, it's very interesting. (PT8, Interview 2 extract)

\subsubsection{Teaching motivation and confidence}

After participating in teaching practicum, all teachers increased their motivation to teach after a period of practical experience in high school. They believe that they will continue to stick with the teaching profession and become teachers in the future. However, most of them want to teach in a new environment, which is less stressful than the situation in high school.

I felt motivated when dealing with pedagogical situations. I found it very interesting when I solved those pedagogical situations, I could inspire students to study, specifically my subject. This is very good. (PT1, Interview 2 extract)

Actually, when considering the future job as an English teacher, I feel it is a bit difficult because in the current teaching environment, there are some things that I know, I have to endure, no matter what environment I have to endure a pressure, but the pressure of being a teacher now I do not want to suffer, and I have the thought of whether I should really endure it or not. (PT7, Interview 2 extract)

\subsubsection{Teaching competences in developing professional identity}

Most of teachers knew how to apply theories which were learnt from training program into practice at high school context. They also considered that the application is not always rigid but should be flexible

\section{ISSN 2455-6378}

and appropriate to use it in accordance with the teaching situations and the level of the students.

My best application is some way of teaching vocabulary. That subject is Method 1, and there are several ways to teach vocabulary. I find it very helpful to learn those things because I can teach vocabulary in many ways and my students really like it. Regarding grammar, I feel like I can learn a little bit, but I taught grammar on my way, I don't use mentor's way because it's so hard. (PT2, Interview 2 extract)

Besides, most of teachers had interesting experiences on their homeroom work although there were some confuses with the way to solve classroom issues. The teachers also realized that outside classroom activities were essential to understand more clearly high school students' characteristic and personalities. As a result, those things aided them improve teaching English profession effectively.

We can know how their personalities are and the situation of the student. Assumes as if a normal teacher has responsible for teaching, just tries to teach but when some of the school's compulsory activities such as extracurricular activities, there will be conversation sessions with students to explore many things related to students. (PT7, Interview 2 extract)

At the end of the practicum, I handed out a note to my students to ask how I used to teach well. The question is if I am a teacher in the future, what will I do with the student, the student will say that I did not curse the student, if the student make mistakes, teachers should give them opportunity to correct those mistakes instead of criticizing. (PT2, Interview 2 extract)

Moreover, teachers found out solutions for unexpected situations. For examples, the teacher cared the capacity of learners and the understanding of language intelligence, gave questions to interact and attract students, produced some expressions on the face and used body language so that the students could know that the teacher listened and was aware of the students' answers.

In general, the teachers well integrated into the educational environment at high school. Although there were some difficulties in following the teaching styles of high school as well as using high school facilities, the teachers still found convenient things and supports during teaching practicum.

\subsubsection{Perceptions of an ideal image of EFL teacher}

Most of teachers thought that their ideal image was presented through teaching methodology, testing and assessment, and classroom management. They thought that the ways teachers managed with these areas in educational environment would reflect what kind of teachers they were.

For me, my professional identity is that of a friendly and close teacher. Although the teaching style will be serious, but in terms of communicating with students, they will use closer words that are not too serious to create a better bond between teachers and students. And I can capture the psychology of the students so they can be ready to share with me as a friend (PT8, Interview 2 extract) 
Besides, pre-service teachers have progressive perceptions of their teachers' images as well as their professional identities. While some of them keep on building their ideal images, some others improve their identities because of influences from instructions of their mentor. No matter how the educational environments changed unexpectedly, they still kept their own identities and even had awareness on improving in the future.

\subsection{Discussion}

This section discusses the key findings of the thesis in relation to the relevant previous studies.

Firstly, the practicum experiences helped preservice teachers were able to conceive their professional identity on how they saw themselves regarding to their duties in high school environment. As Beijaard et al. (2000) claim identity of a teacher was described in terms of the factors influencing what a teacher does across the range that a teacher understands in their own subject area, how to teach and communicate knowledge to students, and willingness to change and adapt new innovative ideas and methodologies. It refers to being able to decide appropriate methods of teaching so that different pedagogical goals can be realized. The findings show that pre-service teachers not only shaped their identity through English teaching but also across homeroom works and extracurricular activities. Accordingly, pre-service teachers considered their English teaching motivation and the new roles of English teachers as educators and inspirers who promote and motivate students to learning English and produce values in their lives.

Besides, English teaching practicum experiences provided pre-service teachers with valuable opportunities to develop their English teaching competences. Firstly, their professional identity was presented through the way they focused on the student's level to know how to use appropriate language in class. Secondly, most of pre-service teachers expected to apply English teaching methodologies into their teaching, specially using information and communications technology in English teaching. Thirdly, pre-service teachers well integrated into the educational environment at high schools. Last but not least, they were aware of their current English capability so that they draw the plan to improve in the future. This finding is concealed with the previous study by Pennington and Richards (2016) who found that English teachers' professional identity is established with the classification of language teachers' professional including foundational competences of language teacher identity and then advanced competences of language teacher identity. This finding also supported by Professional standard of teachers (MOET, 2018) with a system of qualities and competencies that teachers need to achieve in order to implement the teaching and educating students duties at high school.

\section{ISSN 2455-6378}

Additionally, another interesting view is that the teachers cared the capacity of learners and the understanding of language intelligence. Given this, they gave elicit questions to interact and attract students and produced some expressions on the face as well as used body language so that the students could know that the teacher listened and was aware of the students' answers.

Furthermore, mentors shared their teaching experiences, gave positive guides and checked lesson plans thoroughly for pre-service teachers. However, pre-service teachers sometimes though that teaching was just as a show because of mechanically following the lesson plans. A possible explanation for this finding is that pre-service teachers must always follow the instructor. Because of the influences of Vietnamese cultural factors, some preservice teachers are free to innovate in teaching but others are not. Therefore, adapting and learning how to work in teaching culture is part of becoming a teacher in their careers.

Pre-service teachers' personalities and genders are viewed as findings for forming EFL teacher professional identity. The results show that teachers' personality and gender influence the way they use teaching methods and interact with the pedagogical community, as well as their own pedagogical styles and behaviors. This finding is in line with studies conducted by Sugrue (1997) who found that preservice teachers identified features of teaching identities theories depend on their personalities. Lamote and Engels (2010) further stress that professional identity was based on pre-service teachers' gender when they try to attach importance to discipline in the classroom and focus on student involvement.

What is more, EFL pre-service teachers' professional identity was presented through teaching methodology, testing and assessment, and classroom management. It is noted that the findings are different from previous study conducted by Tran and Sanchez (2016) who found the role of formal and informal pre-training learning experiences in the formation of language teacher identity both inside and outside the classroom.

Furthermore, pressures, conflictions and difficult conditions related to teaching community, school disciplines and facilities at high school environment challenged EFL pre-service teachers' professional identity development. This finding is consistent with other studies in the literature (Pillen et al., 2013; Ulvik, Helleve and Smith, 2018). The authors claim that students moving into the role of teachers would face many pressures and difficulties in teaching. Conflicts were considered as the tensions they face when pedagogical practice. A possible explanation for these claims is that pre-service teachers were confused about the differences between theories and practices in the factual settings. Therefore, both practice and theory were necessary to cooperate and 
complement each other to promote students in teacher education profession and a feeling of being a teacher.

\section{Conclusions}

The present study shows that EFL pre-service teachers highly expected to develop their teaching professional identities after teaching practicum. They expected to strengthen teaching motivation and confidence, teaching competences as well as construct their own ideal image and personality of an English teacher. The results of the study shows that great relationships in teaching community including mentors and peers have positive effects on preservice teachers' professional identity development. Besides, interactions between pre-service teachers and high school students contribute to improve their love in teaching and teaching motivation although they sometimes dissatisfied with the low level of high school students. Additionally, high school contexts with various disciplines influenced on preservice teachers' point of view to become high school teachers. Useless extracurricular activities and formal administrative documents, as well as strict regulations in high schools make teachers feel pressured and almost reluctant to teach in the high school environment.

\section{Appendixes}

Appendix 1: Interview Questions (1)

1. How do you think about teaching English?

+ What are your self-confidence in teaching competences when participating in this practicum?

+ In the process of teaching English, which problems make you most unconfident?

2. In your opinion, what role does teaching practicum play in developing English teaching competence?

3. What kind of English teaching competence do you want to develop in the teaching practicum? Why?

4. What do you want from your mentors?

5. What do you want in building relationships with students in your teaching?

6 . What supports will you get in teaching practicum? 7. What will make you most satisfied in the English language teaching process? Why?

8. In your opinion, in the process of teaching practicum, what challenges will you encounter?

+ What will you do to overcome those challenges? 9. What kind of teachers do you want to become through English teaching practicum? Why?

10. What kind of teachers that you fear becoming through English teaching practicum? Why?

11. What will you do to be successful in this teaching practicum?

Appendix 2: Interview Questions (2)

1. In your opinion, what is teacher's professional identity? What are the aspects or characteristics shown?

\section{ISSN 2455-6378}

2. What do you think about teaching profession? What do you think about the role of English teachers at high school?

3. Does this teaching practicum affect your teaching competences?

4. What did you do to improve your teaching competences during the internship?

5. What do you think about your experiences during your teaching practicum?

+ What aspects of the practicum do you think you have improved? Why? Give examples.

6 . In the teaching practicum, what kind of the teacher have you built?

7. What were the difficulties you face in the teaching process?

8. What did you do to overcome difficulties in the practice of pedagogy?

9. How do you evaluate the effectiveness of your own teaching practicum?

+ What are you most satisfied with?

+ What is the most important thing you have learnt?

+ What do you want to learn and develop more?

\section{Acknowledgments}

We would like to send my profound thankfulness to fourth-year students (EFL pre-service teachers studying bachelor of English teacher education at Can Tho University) for their assistance with our data collection though they are busy with their teaching practicum and study

\section{Reference}

[1] Beijaard, D., Meijer, P. C., \& Verloop, N. (2004). Reconsidering research on teachers' professional identity. Teaching and Teacher Education, 20(2), 107-128. https://doi.org/10.1016/j.tate.2003.07.001

[2] Beijaard, D., Verloop, N., \& Vermunt, J. D. (2000). Teachers' perceptions of professional identity: An exploratory study from a personal knowledge perspective. Teaching and Teacher Education, 16(7), 749-764. https://doi.org/10.1016/S0742051X(00)00023-8

[3] Canrinus, E. T. (2011). Teachers' sense of their professional identity. 151.

[4] Canrinus, E. T., Helms-Lorenz, M., Beijaard, D., Buitink, J., \& Hofman, A. (2012). Self-efficacy, job satisfaction, motivation and commitment: Exploring the relationships between indicators of teachers' professional identity. European Journal of Psychology of Education, 27(1), 115-132. https://doi.org/10.1007/s10212-011-0069-2 
[5] Carrington, L., Kervin, D. L., \& Ferry, B. (2008). Virtual practicum experiences to build professional identity. 6.

[6] Chong, S., \& Low, E.-L. (2008). Why I want to teach and how I feel about teaching-Formation of teacher identity from pre-service to the beginning teacher phase. Educational Research for Policy and Practice, $\quad 8(1), \quad 59$. https://doi.org/10.1007/s10671-008-9056-Z

[7] Gay, L. R., Mills, G. E., \& Airasian, P. W. (2012). Educational research: Competencies for analysis and applications (10th ed). Boston: Pearson.

[8] Ivanova, I., \& Skara-MincLne, R. (2016). Development of Professional Identity During Teacher's Practice. Procedia Social and Behavioral Sciences, 232, 529536.

https://doi.org/10.1016/j.sbspro.2016.10.073

[9] Larsen-Freeman, D., \& Anderson, M. (2011). Techniques and principles in language teaching (3rd ed). Oxford; New York: Oxford University Press.

[10] Marais, L. M., \& Nel, C. (2018). MultiModal Formative Feedback: Practicum Experiences. 10318-10325. https://doi.org/10.21125/edulearn.2018.250 9

[11] MOET. (2018). Thông tu ban hành quy định chuẩn nghề nghiệp giáo viên co sở giáo dục phổ thông (Circular issued regulations on professional standards for teachers of general education institutions). Hanoi: Vietnam.

[12] Nguyen, M. H. (2017). Negotiating contradictions in developing teacher identity during the EAL practicum in Australia. Asia-Pacific Journal of Teacher Education, 45(4), 399-415. https://doi.org/10.1080/1359866X.2017.129 5132

[13] Pennington, M. C., \& Richards, J. C. (2016). Teacher Identity in Language Teaching: Integrating Personal, Contextual, and Professional Factors. RELC Journal, 47(1), 5-23. https://doi.org/10.1177/0033688216631219

[14] Pillen, M., Beijaard, D., \& Brok, P. den. (2013). Professional identity tensions of beginning teachers. Teachers and Teaching, 19(6), 660-678. https://doi.org/10.1080/13540602.2013.827 455
[15] Richards, J. C. (2010). Competence and Performance in Language Teaching. RELC Journal, 41(2), 101-122. https://doi.org/10.1177/0033688210372953

[16] Salehnia, N., \& Ashraf, H. (2015). On the Relationship between Iranian EFL Teachers' Commitment to Professional Ethics and their Students' Self-Esteem. Mediterranean Journal of Social Sciences. https://doi.org/10.5901/mjss.2015.v6n5s1p1 35

[17] Sugrue, C. (1997). Student Teachers' Lay Theories and Teaching Identities: Their implications for professional development. European Journal of Teacher Education EUR J TEACH EDUC, 20, 213-225. https://doi.org/10.1080/0261976970200302

[18] Tran, B.-L., \& Sanchez, H. S. (2016). The person and the teacher: A case study into language teacher identity formation. 18.

[19] Turbill, J., \& Kervin, L. (2007). Developing a professional identity: First year preservice teachers inschool experience project. 10.

[20] Ulvik, M., Helleve, I., \& Smith, K. (2018). What and how student teachers learn during their practicum as a foundation for further professional development. Professional Development in Education, 44(5), 638-649. https://doi.org/10.1080/19415257.2017.138 8271

[21] Vietnamese Prime Minister. (2017). Quyết định Phê duyệt và Bổ sung Đề án dạy hoc ngoại ngũu trong hệ thống giáo duc quốc dân giai đoạn 2017-2025 (Decision approval of adjustment and supplement on "The project of teaching and learning foreign languages in the national educational system). Retrieved from https://thuvienphapluat.vn/van-ban/Giaoduc/Quyet-dinh-2080-QD-TTg-2017-bosung-De-an-day-hoc-ngoai-ngu-trong-hethong-giao-duc-quoc-dan-370658.aspx

[22] Zhu, J., \& Zhu, G. (2018). Understanding student teachers' professional identity transformation through metaphor: An international perspective. Journal of Education for Teaching, 1-5. https://doi.org/10.1080/02607476.2018.145 0819

[23] Zivkovic, P. (2016). The Nexus Between Teacher Professional Identity And Some Socio-Demographic And Psychological Variables. 14. 
[24] Zlatković, B., Stojiljković, S., Djigić, G., \&

Todorović, J. (2012). Self-concept and Teachers' Professional Roles. Procedia Social and Behavioral Sciences, 69, 377384.

https://doi.org/10.1016/j.sbspro.2012.11.423 